\title{
BIMBINGAN BERBASIS EKSPERIENSIAL UNTUK MENGEMBANGKAN KESADARAN MULTIKULTURAL
}

\author{
Fina Mufliq Khatul Ngulya \\ Email: Finaulya28@gmail.com
}

\begin{abstract}
Abstrak
Tulisan ini didasari oleh terbiasanya masyarakat untuk berprasangka kepada orang asing atau baru, hal itu disebabkan oleh kurangnya pengetahuan terhadap perbedaan budaya. Kesadaran multikultural merupakan kompetensi yang harus dikembangkan agar individu dapat memaklumi perbedaan sebagai keberagaman, dan memiliki sikap yang positif untuk hidup dalam keberagaman. Hal tersebut memerlukan pengalaman langsung yang dapat dirasakan oleh siswa. Pendekatan experiensial dalam tulisan ini disarankan untuk digunakan guru BK dalam mengembangkan kesadaran multikultur siswa melalui bimbingan kelompok. Penggunaan teknik-teknik dalam experiensial mempermudah siswa memahami keberagaman melalui pengalaman langsung sebagai media utama, selain itu siswa dapat mencoba mensimulasikan perilaku yang tepat ketika menghadapi masalah yang disebabkan oleh perbedan budaya.
\end{abstract}

Kata kunci : bimbingan kelompok, experiential, kesadaran multikultural

\section{PENDAHULUAN}

Kompetensi multikultur yang harus dimiliki siswa menurut Moule (2012) antara lain : 1) kesadaran, 2) sikap, 3) pengetahuan, 4) keterampilan. Kesadaran (awarness) merupakan kemampuan untuk merasakan dan bereaksi terhadap perberbedaan. Dalam kehidupan sehari hari, seringkali kita berprasangka kepada orang asing atau baru, hal itu disebabkan oleh kurangnya pengetahuan terhadap perbedaan budaya. Sadar akan perbedaan berarti memiliki pengetahuan, dan pemahaman yang mendalam tentang perbedaan, dan mampu menyikapinya dengan positif. Sebagai kompetensi multikultural, kesadaran multikultural (multicultural awareness) akan mempengaruhi sistem kepercayaan dan nilai seseorang tentang budaya lain. Kompetensi tersebut akan terwujud dari cara berkomunikasi baik secara verbal maupun non verbal. Kesadaran multikutural harus dimiliki oleh siswa, baik dalam konsteks pertemanan maupun bermasyarakat secara luas. Hakikatnya keberagaman budaya merupakan sumber dari kreativitas, kekayaan intelektual, dan pengembangan sikap-sikap toleran. Fluerentin (2012) berpendapat dengan mengembangkan kesadaran multikultural, memungkinkan siswa dapat menjembatani perbedaan antara dirinya dengan lingkungannya oleh karena itu, siswa harus dilatih peka, 
bersikap empati, menghormati keragaman dan perubahan, serta dapat memahami diri dan lingkungannya.

Selanjutnya Khusumadewi et. al. (2017) mengemukakan manfaat pengembangan Cultural Awareness antara lain sebagai berikut.

1) Memiliki pemahaman yang kuat tentang budaya dan yang bukan budaya.

2) Memahami bagaimana orang memperoleh budaya dan peran penting budaya dalam identitas pribadi, cara hidup, dan kesehatan mental dan fisik individu dan masyarakat.

3) Menyadari berbagai bentuk budaya, nilai-nilai, keyakinan, persepsi, dan bias.

4) Dapat mencari dan berpartisipasi dalam interaksi yang bermakna dengan orang-orang dari berbagai latar belakang budaya yang berbeda.

Proses menyadari pada dasarnya melibatkan kegiatan berpikir, merasa, dan mencoba melakukan sesuatu. Oleh karena itu pengembangan kesadaran multikultur tidak akan optimal jika hanya diberikan pengetahuan saja. Siswa harus secara langsung menemukan perbedaan di sekitarnya.

Bimbingan kelompok pendekatan experiential menekankan pengalaman sebagai media untuk proses pengembangan kesadaran siswa. Pendekatan experiential menitik beratkan pada partisipasi aktif individu secara langsung untuk mentransformasi pengalaman ke dalam diri individu dalam setting yang dibuat seperti kehidupan nyata (Wulandari, 2016). Oleh karena itu penulis tertarik untuk membahas lebih dalam mengenai teknik dan konten bimbingan berbasis experiential yang dapat menjadi alternatif upaya mengembangkan kesadaran multikultural siswa.

\section{PEMBAHASAN}

\section{a. Konsep Kesadaran Multikultural}

Akhmadi (2016) mendefinisikan kesadaran multikultural merupakan kemampuan mengenali berbagai perbedaan dan persamaan budaya serta kemampuan memandang perbedaan sebagai keragaman. Individu yang memiliki kesadaran multikultural tidak akan mempermasalahkan perbedaan, bagi mereka berbeda itu bukan sebuah masalah.

Dalam beberapa kajian, kesadaran multikultural menekankan pada proses untuk mengenali, memahami, dan menghargai budaya. Lebih dalam lagi kesadaran multikultural berfokus kepada ciri khas diri seseorang, sehingga melihat perbedaan bukan sebagai normal tidaknya seseorang.

Sue \& Sue (Zen \& Atmoko, 2015) menerangkan ciri- ciri seseorang yang memiliki kesadaran multikultural, sebagai berikut.

1) Meyakini pentingnya kepekaan dan kesadaran pada warisan budaya setiap individu.

2) Menyadari latar belakang dan pengalaman-pengalaman budaya yang dapat mempengaruhi sikap dan nilai-nilai serta bias-bias terhadap proses psikologis. 
3) Mengenali batas kemampuan dan keahlian diri sendiri pada keragaman budaya.

4) Mengenali sumber rasa ketidaknyamanan ketika berhubungan dengan sesama yang memiliki kultur berbeda.

5) Menyadari reaksi emosi negatif dan positif pada orang lain yang berbeda kultur yang terkadang mengacaukan keharmonisan hubungan antara sesama.

6) Berani mempertentangkan keyakinan dan perilakunya dengan sesama teman yang memiliki perbedaan kultur tanpa menghakimi.

7) Menyadari stereotip terhadap kelompok ras, etnis dan siswa minoritas.

8) Menghargai nilai-nilai agama tertentu, karena hal ini mempengaruhi tatapandang dan fungsi psikososial.

9) Menghargai ragam bahasa daerah dan menilai perbedaan bahasa bukanlah penghambat terciptanya hubungan sosial yang baik.

Kesadaran multikultural sebagai kompetensi siswa dapat ditemukan dalam Standar Kompetensi Kemandirian Peserta Didik (SKKPD). Dalam Panduan Operasional Pelaksanaan Layaan BK (POP BK) kompetensi siswa yang termasuk kesadaran multikultural antara lain sebagai berikut.

1) Mampu mempelajari keragaman interaksi sosial

2) Mampu menyadari nilai-nilai persahabatan dan keharmonisan dalam konteks keragaman interaksi sosial, dan
3) Dapat berinteraksi dengan orang lain atas dasar kesamaan (equality).

Dapat disimpulkan bahwa kesadaran multikultural membuat siswa dapat menjalin pertemanan dengan harmonis. Siswa memahami perbedaan karakteristik di lingkungan pertemannya, dan memelihara pertemanan dengan melakukan perilaku yang tepat di tengah perbedaan, tanpa diskriminasi, dan menghargai satu sama lainnya.

\section{b. Pendekatan Experiential Dalam Bimbingan Kelompok}

Pendekatan experiential merupakan konsep teori yang populer oleh Kolb. Dalam teorinya, Kolb percya bahwa pengalaman langsung dapat memabantu siswa menemukan makna sendiri dari konten yang dipelajarinya. Sehingga pengalaman merupakan kunci utama keberhasilan belajar dan perubahan perilaku seseorang.

Dalam experiential learning, pengalaman memiliki peranan penting dalam proses belajar, dan menjadi pembeda dengan pendekatan lainnya. Sesuai dengan pendapat Mugiarso \& Haksasi (2017) bahwa istilah "experiential" untuk membedakan antara teori belajar kognitif yang cenderung menekankan kognisi lebih daripada afektif.

Dalam praktiknya, bimbingan kelompok experiential akan melibatkan empat aspek yaitu 1) tubuh, 2) pikiran, 3) perasaan, 4) tindakan. Oleh karena itu, siswa akan mengembangkan keterampilan secara aktif ketika mengikuti kegiatan bimbingan. 
Secara umum proses bimbingan kelompok menggunakan experiential akan membentuk sebuah siklus. Kolb menerangkan siklus yang ada dalam pendekatan experiential meliputi pengalaman nyata, pengamatan reflektif, konseptualisasi abstrak, dan eksperimen aktif.

Untuk mencapai siklus tersebut, Rusmana (2009) menguraikan langkahlangkah sebagai berikut.

1) Eksperientasi, proses ini diarahkan untuk memfasilitasi siswa mengalami dan mengekspresikan perasaanperasaan sesuai dengan skenario/ rencana bimbingan yang telah ditetapkan sebelumnya.

2) Identifikasi, guru BK melakukan identifikasi dan refleski atas pengalaman yang dilakukan pada tahap eksperientasi. Pada tahap ini, siswa menilai lebih dalam perilaku yang dilakukan dalam tahap sebelumnya untuk melihat hubungan antara proses yang dilakukan dengan keadaan dirinya. Siswa mengungkapkan pikiran dan perasaan yang terkait dengan proses eksperientasi.

3) Analisis, siswa diajak untuk merefleksikan dan memikirkan hubungan antara proses yang sudah dilakukan dengan keadaan dirinya, dari proses berfikir reflektif ini, diharapkan ada gambaran mengenai apa yang akan dilakukan dalam proses perbaikan diri.

4) Generalisasi, proses dimana siswa merencakan tindakan untuk proses perbaikan dan pengembangan agar memiliki sikap ataupun perilaku yang lebih baik.

\section{c. Teknik Bimbingan Kelompok Experiential \\ Mengembangkan \\ Multikultural}

Umumnya teknik- teknik

bimbingan kelompok experiential berisi pengalaman yang menuntut siswa untuk aktif. Beberapa teknik yang dapat dilakukan antara lain sebagai berikut.

1) Sosiodrama

Sosiodrama sebagai bentuk bermain peran memfasilitasi siswa untuk merasakan situasi keberagaman budaya melalui peran yang dimainkan. Penggunaan sosiodrama dalam bimbingan kelompok mengembangkan kognitif dan afektif siswa dengan cara mensimulasikan situasi kehidupan nyata.

Dalam bermain peran siswa mungkin akan menemukan konflik atau situasi bermasalah. Sosiodrama pun memfasilitasi siswa mengidentifikasi sikap - sikap yang tepat dalam situasi sosial, sehingga mereka akan berusaha menemukan perilaku atau sikap yang tepat dalam menghadapi situasi tersebut.

2) Membahas Film dan Buku Bacaan.

Film dan buku bacaan dapat diterapkan dalam model experiential daam konsep lain disebut sebagai terapi sinema, biblio konseling, dan latihan common reading.

Ketika siswa membaca buku atau menonton film, mereka akan mendapatkan pengalaman dan kesan 
emosional yang mendalam. Film dan buku bacaan dapat menjadi role model yang dapat membantu siswa menerjemahkan teori atau konsep yang abstrak. Dengan kata lain melalui kegiatan tersebut siswa dapat melakukan identifikasi dan refleksi mengenai keberagaman, dan bagaimana harus bersikap di tengah keberagaman.

3) Group excercise

Group excercise merupakan teknik dalam bimbingan kelompok yang menekankan pada latihan bersama anggota kelompok. Nugraha \& Imanuddin (2019) berpendapat melalui model experiential group excercise siswa berkesempatan untuk saling membantu, saling memberi wawasan/informasi, saling bertukar pengalaman dan saling memberi alternatif penyelesaian masalah ilustratif yang sedang dihadapi oleh kelompok.

Pengunaan excercise memberikan rasa senang dan memudahkan siswa untuk terbuka akan dirinya, sehingga siswa akan lebih mudah mengenali ciri khas setiap orang. Beberapa bentuk latihan yang dapat dilakukan antara lain latihan melingkar (round), latihan menulis, dyad \& triad, dan dilema moral.

\section{PENUTUP/ KESIMPULAN}

Kesadaran multikultural bukanlah tentang mengetahui adanya perbedaan satu sama lain, tetapi memahami perbedaan sebagai keberagaman dan bagaimana hidup dalam keberagaman. Oleh karena itu pendekatan experiential dirasa akan mampu mengembangkan kesadaran multikultural karena didasari oleh pengalaman langsung sebagai media nya. Guru BK dapat menerapkan pendekatan experiential dalam bentuk bimbingan kelompok.

\section{DAFTAR PUSTAKA}

Akhmadi, A. (2016). Peningkatan Kesadaran Multikultural Konselor (Guru BK). Muaddib: Studi Kependidikan Dan Keislaman, 3(2), 18-36

Fluerentin, E. (2014). Latihan Kesadaran Diri (Self Awareness) Dan Kaitannya Dengan Penumbuhan Karakter. Jurnal Inspirasi Pendidikan, 1(1).

Khusumadewi, A., WS, H. W., \& Wiyono, B. D. (2017). Pengembangan Modul Cultural Awareness Untuk Konselor Sebaya. Bikotetik (Bimbingan dan Konseling: Teori dan Praktik), 1(1), 30-36.

Mugiarso, H., \& Haksasi, B. S. (2017). Muatan Pendidikan Karakter Berbasis Experiential Learning dalam Konseling Kelompok. In Prosiding Seminar Bimbingan dan Konseling (Vol. 1, No. 1, pp. 218-226).

Nugraha \& Imaddudin. (2019). Experiential Based Counseling Untuk Meningkatan Komitmen Belajar Siswa Sekolah Menengah Atas Di Wilayah Kecamatan Indihiang Kota Tasikmalaya. Journal of Innovative Counseling : Theory, Practice \& Research, 3 (1): pp. 36-42 
Wulandari, S. (2016). Pengembangan Model Bimbingan Kelompok Dengan Teknik Experiential Learning Untuk Meningkatkan Empati Siswa SMP Negeri Kota Semarang. (Doctoral dissertation, Universitas Negeri Semarang)

Zen, E. F., Atmoko, A. (2015). Model Psikoedukasi Cognitive StageExperiential Untuk Meningkatkan Kesadaran Multikultural. LPPM Universitas Negeri Malang. Diunduh dari http://1p2m.um.ac.id/wpcontent/uploads/2015/02/ELLAFARIDATI-ZEN_artikel.doc. 